
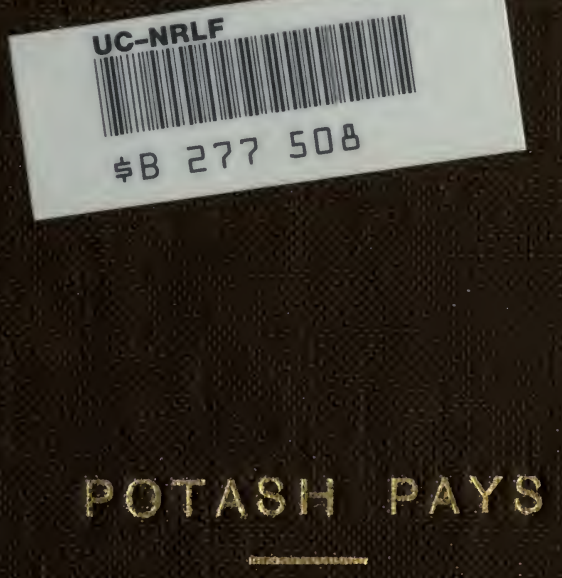

GERMAN KALI WORKS 

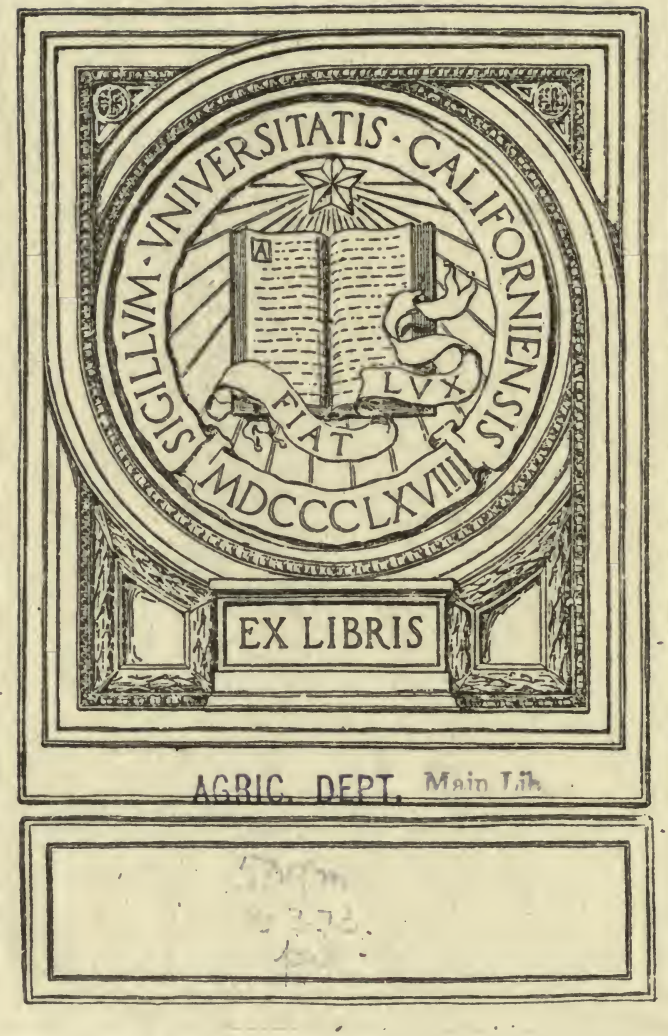


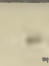




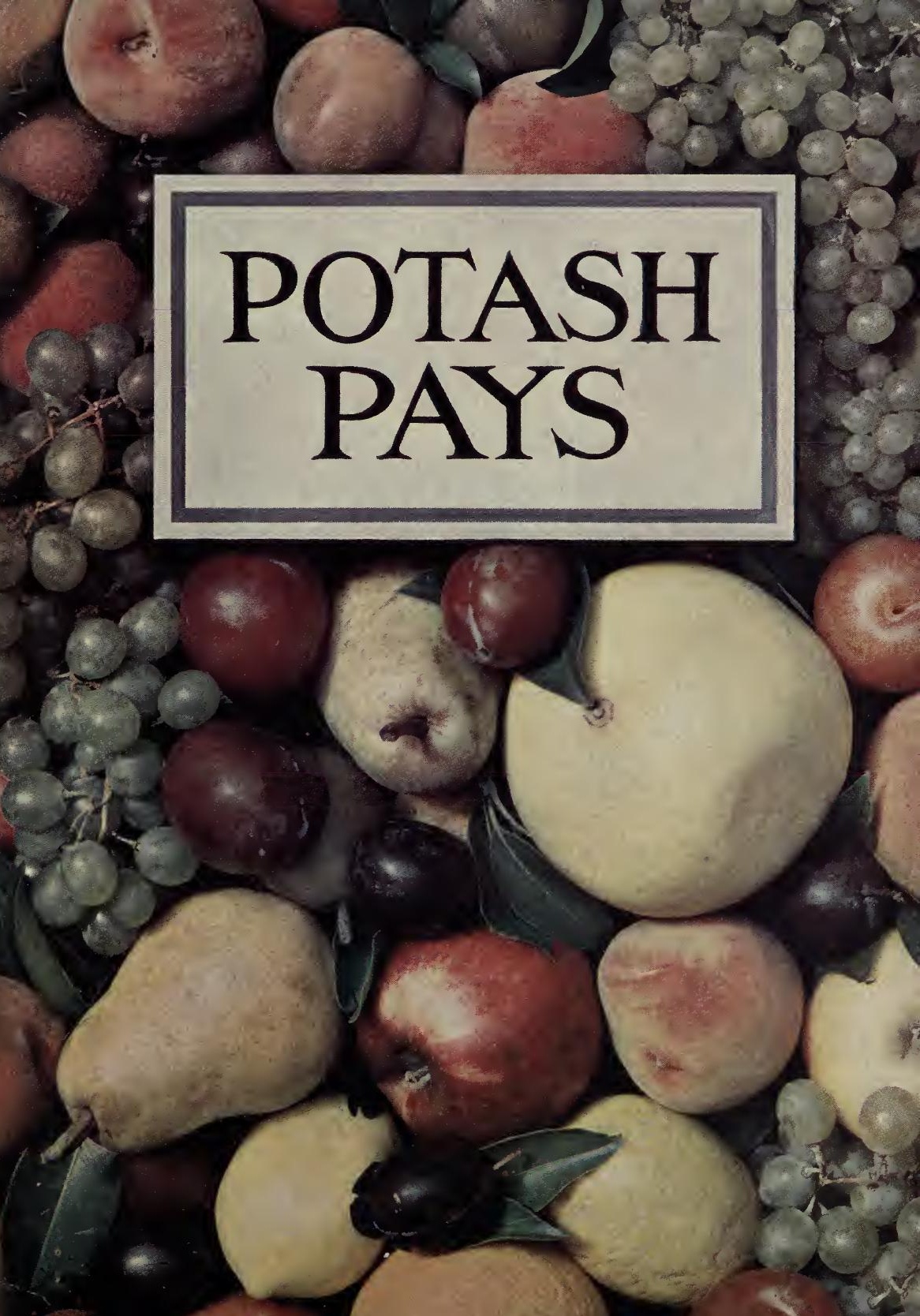


Digitized by the Internet Archive in 2007 with funding from Microsoft Corporation 


\section{POTASH PAYS}

Practical suggestions to farmers showing how to use fertilizers with profit

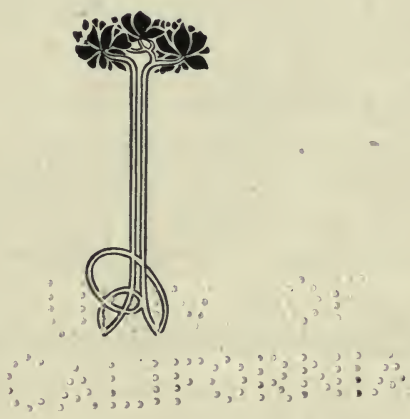

Published by

\section{THE GERMAN KALI WORKS,}

(INCORPORATED)

NEW YORK,

42 BROADWAY

ATLANTA, GA.

1212 EMPIRE B'LD'G.
CHICAGO, ILL.

MONADNOCK BLOCK

SAN FRANCISCO, CALIF. 


\section{$\mathcal{N O T I C E}$}

Every farmer can obtain, free of charge, a copy of the following agricultural books.

POTASH IN AGRICULTURE

COTTON CULTURE (REVISED)

TOBACCO CULTURE

TROPICAL PLANTING

STASSFURT INDUSTRY

SUGAR CANE CULTURE

THE COW PEA

PLANT FOOD

TRUCK FARMING

WHY THE FISH FAILED

FARMER'S NOTE BOOK

STRAWBERRY CULTURE

ORANGE CLLTURE

VALUE OF SWAMP LANDS

SUGAR BEET CULTURE

State which of the above mentioned publications you desire, and tit we mailed to youfree of charge.

A D D R E S S :

GERMAN KALI WORKS,

New York, N. Y.

42 Broadway

Atlanta, Ga.

1212 Empire B'ld'g.
Chicago, Ill.

448 Nonadnock Blk. Whitney Bank B'ld'g.

San Francisco, Calif. 


\section{POTASH PAYS}

MERICAN farmers and fruit growers are rightly regarded as the most intelligent, enterprising, and prosperous of their class. Our farmers make a success of their business, because they are up-to-date and ever ready and quick to adopt the latest improvements and the newest methods. They take advantage of the teachings of science, and make practical use of recent discoveries, whereby they increase the fertility of their lands and gather large and profitable crops.

It is no wonder, then, that our farmers in California and other States now pay so much attention to theimportant subject of supplying plant food to their different lands. They not only know, but they have found out that it is necessary to put back into the soil those substances which have been taken out year after year by their crops. Science has shown that potash, phosphoric acid and nitrogen are continually used up from the soil by growing crops. Unless these substances are returned in the form of fertilizers, the farmer's lands will surely and steadily lose their productiveness, and sooner or later his yields of grains, or fruits, or vegetables, as the case may be, will become less and less.

No matter how rich the soil may be, the result is the same, when crop after crop is gathered from the same land. And so when a farmer is asked: "Why do you fertilize your land?" He at once replies "To feed my crops." Fertilizers 
are crop foods. It is simply a question of feeding the crops, as it is in feeding live stock on the farm. Just as different animals require different kinds and amounts of food, so the different soils and crops need certain substances, which are contained in a proper fertilizer, for their best development or condition.

Some farmers and fruit growers in California and other States may cling to the old notion that, as the soil is still new, it does not need potash and the other elements which have been removed by the successive crops. But this is a mistake. If they did not need potash, California farmers would not buy the large quantities which they do at the present time. Those who are using potash on their farms and orchards in California are getting a good profit on their investment. Their opinion that "potash pays" is the best testimony to its value. Such an opinion is based upon practical experience and upon the actual results from the increased crops which they obtain from the proper use of potash with the other necessary ingredients.

While certain tests with certain soils in California have shown that they contained considerable potash, yet the important question is: "How much of this potash is available as plant food?" Or, the question may be asked: "Is this potash naturally in the soil in a soluble condition?" If the potash is in an insoluble condition it is useless to plant growth, and potash fertilizers must be used in order to obtain proper yields. The mere statement that a chemical analysis shows considerable potash in a soil is not sufficient, for by present chemical methods it is impossible to determine the quantity of plant food which is available to the different plants growing on the soil.

How many of our readers ever carefully considered the large quantities of potash, phosphoric acid, and nitrogen 
which are lost, so to speak, each year? Do you know the number of pounds of valuable potash taken per acre by any of the leading crops? If not, you should read and study this list:

Table Showing the Amount of Potash Removed by Crops and Quantity of Potash Salts Needed to

Return Fertility to the Soil

\begin{tabular}{|c|c|c|c|}
\hline Crop & Yield & $\begin{array}{l}\text { Actual Potash } \\
\text { Removed }\end{array}$ & $\begin{array}{l}\text { Muriate or Sulfate } \\
\text { of Potash Needed to } \\
\text { Return Fertility }\end{array}$ \\
\hline Apples & 15 tons & 60 lbs. & 120 lbs. \\
\hline Barley & *30 bu. & $51.1 \mathrm{bs}$. & 102 lbs. \\
\hline Beans & *30 bu. & $53 \mathrm{lbs}$. & $106 \mathrm{lbs}$. \\
\hline Buckwheat & *34. bit. & $401 \mathrm{bs}$ & 80 lbs. \\
\hline Cabbage & 30 tons & 270 lbs. & 540 lbs. \\
\hline Clover (dry) & 2 tons & 88 lbs. & $176 \mathrm{lbs}$. \\
\hline Corn & *70 bu. & 55 lbs. & 110 lbs. \\
\hline Grapes & *2 tons & 39 lbs. & 78 lbs. \\
\hline Hops & *600 lbs. & $53 \mathrm{lbs}$ & 106 lbs. \\
\hline Mixed Hay & $21 / 2$ tons & 77 lbs. & 154 lbs. \\
\hline Oats & *60 bu. & $621 \mathrm{bs}$. & 124 lbs. \\
\hline Onions & $221 / 2$ tons & $72 \mathrm{lbs}$ & 144 lbs. \\
\hline Pears & 16 tons & $26 \mathrm{lbs}$. & 52 lbs. \\
\hline Peas & *30 bu. & $52 \mathrm{lbs}$. & 104 lbs. \\
\hline Plums & 8 tons & 40 lbs.. & 80 lbs. \\
\hline Potatoes & *200 bu. & 74 lbs. & 148 lbs. \\
\hline Rye & *30 bu. & 45 lbs. & 90 lbs. \\
\hline Sugar Beets & ${ }^{*} 15$ tons & 143 lbs. & 286 lbs. \\
\hline Timothy Hay & 2 tons & 94 lbs. & 188 lbs. \\
\hline Tomatoes & 10 tons & 54 lbs. & 108 lbs. \\
\hline Wheat & *35 tons & 31 lbs. & 62 lbs. \\
\hline
\end{tabular}

* Note: Includes straw,stover, vines, pods, etc, in addition. 
All of the foregoing crops also remove from the soil the other two essential elements of plant food, which are phosphoric acid and nitrogen. Of course it is quite necessary that all three of these plant foods be present in the soil in order that the growing crops get suitable food or nourishment. Potash, phosphoric acid, and nitrogen each have their own value and do their separate work; so that one can not take the place of the other. A proper mixture of these three ingredients makes what is known as a "complete fertilizer." The average farmer can usually make his own mixtures. In fact, many farmers prefer to buy their potash and other plant foods and mix them to suit their soil and their different crops. The amounts of potash, phosphoric acid, and nitrogen depend on the nature and condition of the soil, as well as on the kind of crop to be grown:

Another important point to remember is, that the quantities of plant food which each crop actually requires can not be measured by the exact number of pounds of potash and the other plants foods removed by that crop from the soil. The reason is that plant roots can only reach a certain amount of plant food in the soil, while the rest is not taken up. Therefore, practical tests and experience have shown that larger quantities of potash, phosphoric acid, and nitrogen must be supplied than the actual number of pounds per acre removed by the yield.

The practical farmer and fruit grower will ask: "How can I find out just what kind and how much fertilizing material I should use for such - and-such a crop?"

In reply, we would suggest that the farmer or fruit grower make a few simple tests of fertilizers for himself, and this each one can do at a very small amount of trouble and expense.

The best way is to lay out "experimental plots." You 
should take small plots of ground of the same size and give each one the same kind of treatment, except as to its fertilization. Three such plots may be laid out as follows:

\section{Plot No. 1 \\ Check Plot - No Fertilizer Applied}

\section{Plot No. 2}

Use c complete Fertilizer, containing Potash, Phosphoric Acid and Nitrogen

\section{Plot No. 3}

Apply an "Incomplete Fertilizer," containing only Phosphoric Acid and Nitrogen

Now compare the results. The difference in yields on Plots Nos. 1 and 2 will show the gain from using a complete fertilizer on the land.

The difference in the yields on Plots 2 and 3 will show the loss from not having Potash in the fertilizer.

Just such experiments have been made by a number of practical farmers in California. They cover a wide range of soils in that State and many different crops. The interesting results thus obtained are set forth in the following pages. 


\section{EXPERIMENT ON PEACHES}

This experiment, made by Mr. H. E. Butler, for the Penryn Fruit Company, clearly demonstrates the value of fertilizers for the orchard. Moreover, it clearly shows the value of Potash in producing large yields of superior fruit.

The Lovell peach was the subject of the test and the soil over the acre used for the experiment was a clay loam with a decomposed granite subsoil. The trees were six years old at the time the experiment was started in 1906 . There was a crop failure during that year but quite satisfactory crops were harvested in 1907 and 1908 , as shown in the following table:

\begin{tabular}{|c|c|c|c|c|c|}
\hline \multirow[t]{2}{*}{ Plot } & $\begin{array}{l}\text { Fertilizer applied per acre } \\
\text { in pounds }\end{array}$ & \multicolumn{2}{|c|}{$\begin{array}{l}\text { Yields per acre } \\
\text { in pounds }\end{array}$} & \multicolumn{2}{|c|}{$\begin{array}{l}\text { Increase over } \\
\text { unfertilized plot }\end{array}$} \\
\hline & & 1907 & 1908 & 1907 & 1908 \\
\hline 1 & No fertilizer & 6150 & 7500 & - & - \\
\hline 2 & $\begin{array}{l}120 \text { Muriate Potash } \\
600 \text { Superphosphate } \\
180 \text { Nitrate Soda }\end{array}$ & 12300 & 20000 & 6150 & 12500 \\
\hline 3 & $\begin{array}{l}600 \text { Superphosphate } \\
180 \text { Nitrate Soda }\end{array}$ & $\$ 610$ & 12500 & 2460 & 5000 \\
\hline
\end{tabular}

In 1907 increase from 120 pounds of Muriate of Potash par acre, was 3690 pounds Peaches. In 1908 increase from 12) pounds of Muriate of Potash per acre, was 7500 pounds Peaches. Average increase from 120 pounds of Muriate of Potash per acre, was 5595 pounds Peaches. 
Comparative Yields, 1908. Experiment by H. E. Butler, Penryn, Cal.

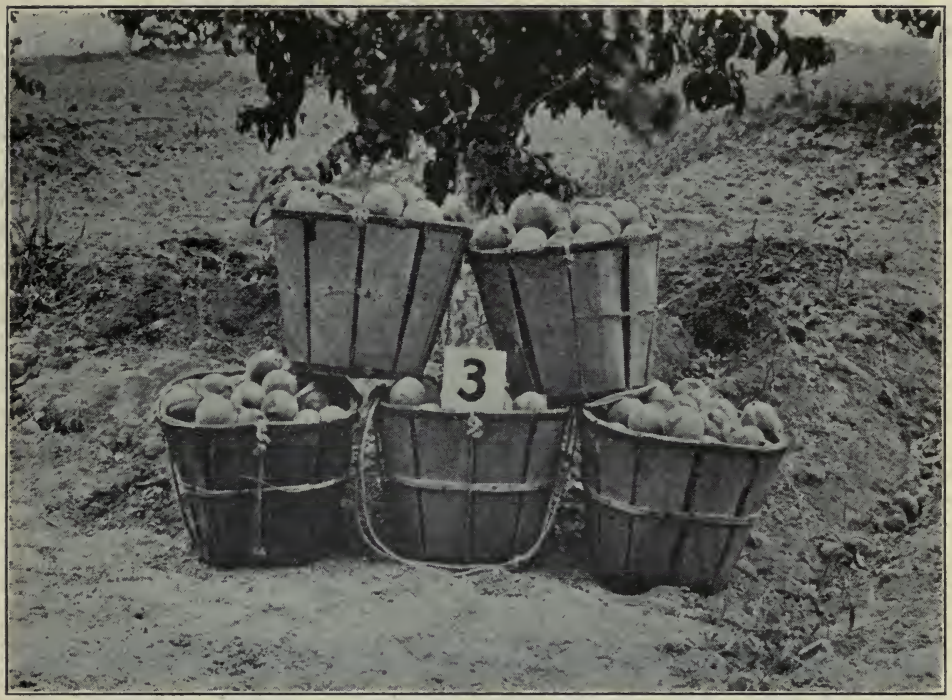

Incomplete Fertilizer (NO POTASH) Yield, $61 / 4$ tons per acre .....

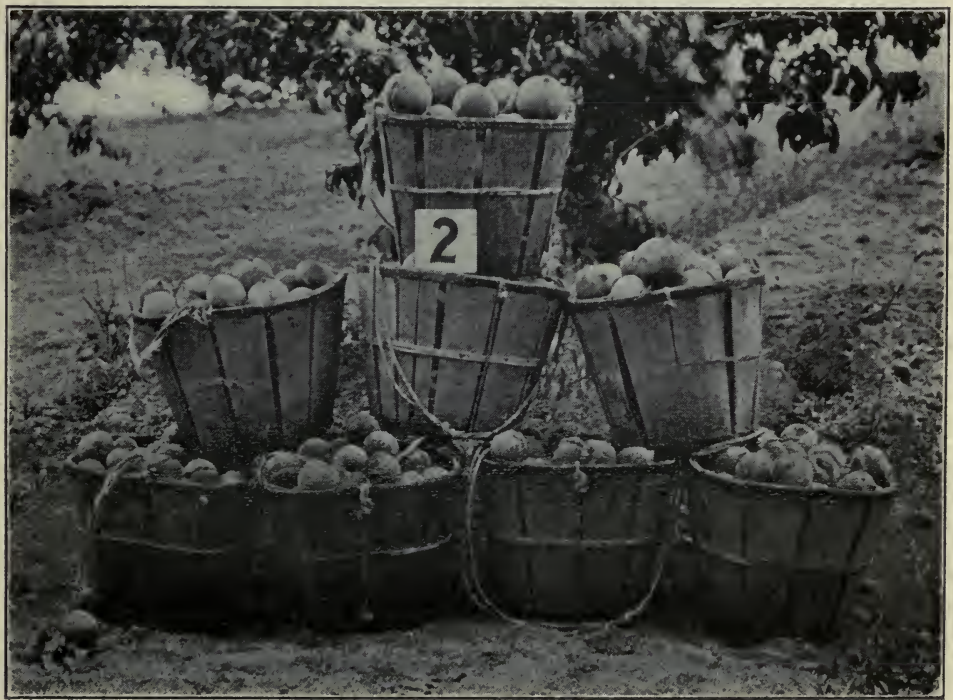




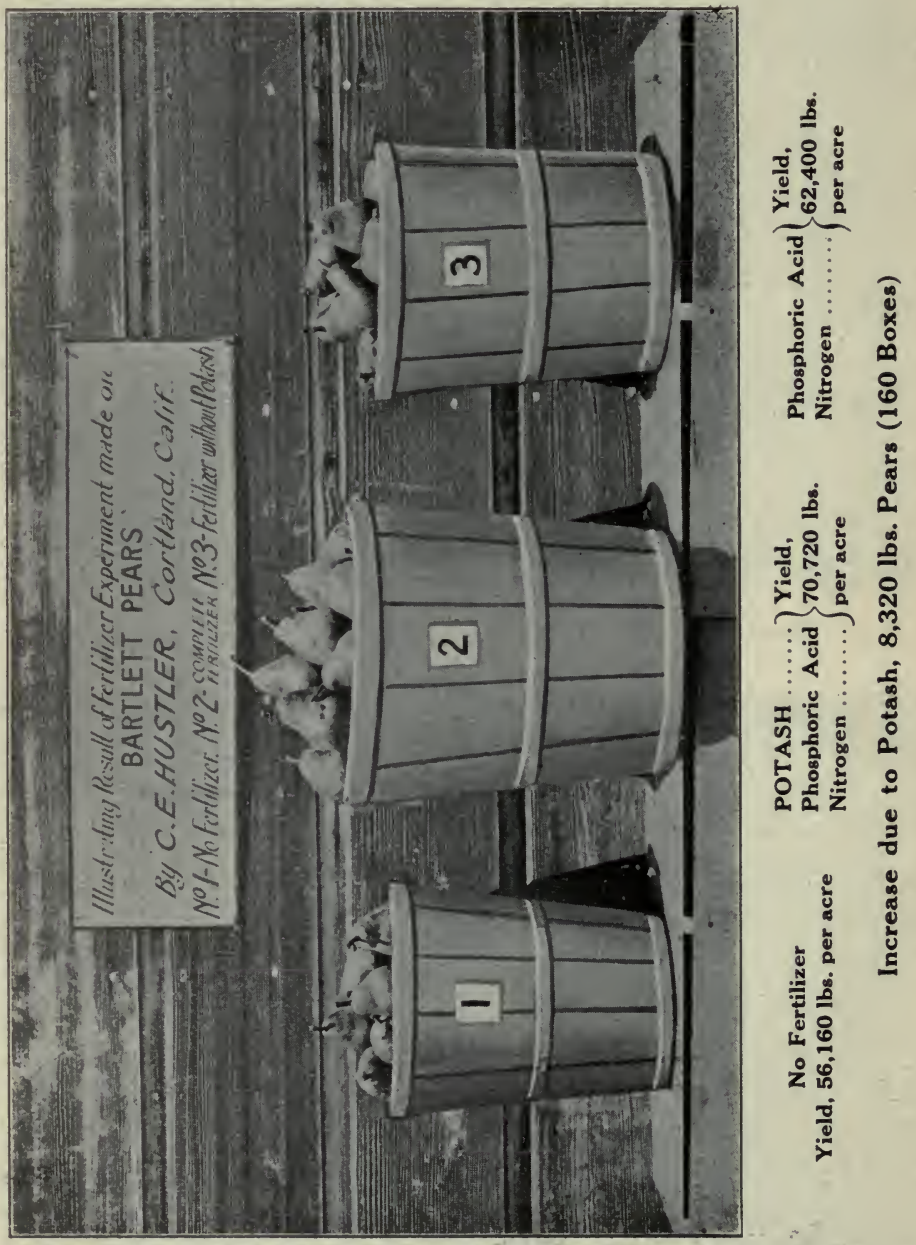




\section{EXPERIMENT ON BARTLETT PEARS}

This experiment, by Mr. C. E. Hustler, Cortland, Cal., was conducted on sandy loam soil in an orchard 25 years old and on trees in good bearing condition. Although there was trouble from blight in some parts of the orchard, this did not affect the results of the experiment.

The following is an account of the amount of fertilizer applied, the yields, and the increase due to the use of fertilizers:

\begin{tabular}{l|l|c|c}
\hline Plot & Fertilizer per acre in pounds & $\begin{array}{c}\text { Yield per acre } \\
\text { in pounds }\end{array}$ & $\begin{array}{c}\text { Increase per acre } \\
\text { over unfertilized } \\
\text { in pounds }\end{array}$ \\
\hline 1 & $\begin{array}{l}\text { No fertilizer } \\
180 \text { Sulfate of Potash } \\
600 \text { Acid Phosphate } \\
180 \text { Dried Blood } \\
600 \text { Acid Phosphate } \\
180 \text { Dried Blood }\end{array}$ & 56160 & 14560 \\
\hline
\end{tabular}

Increase from the use of the complete fertilizer was 280 "picking" boxes averaging 52 pounds each. The increase from the use of 180 pounds of Sulfate of Potash was 160 'picking"' boxes. 


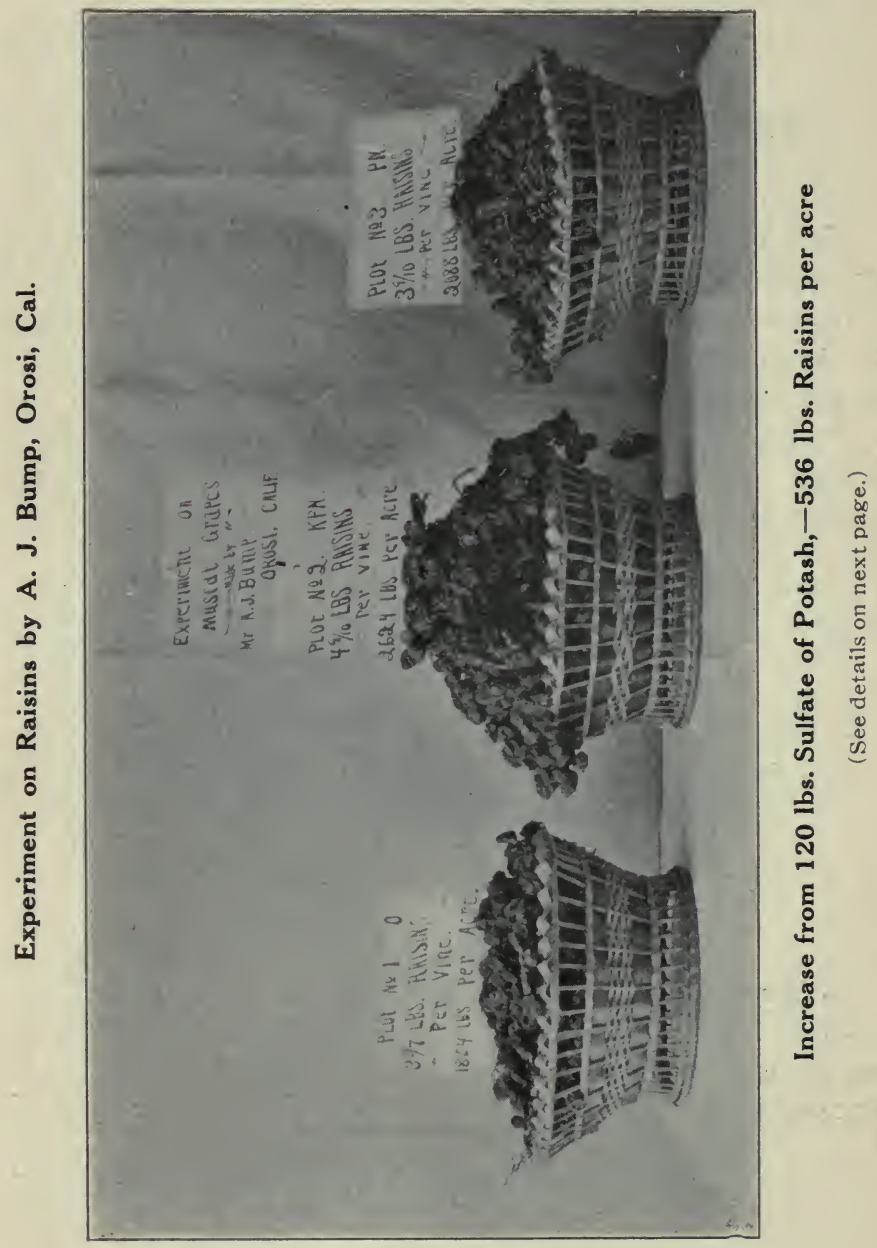




\section{EXPERIMENTS ON RAISIN GRAPES}

The experiment illustrated on the preceding page, conducted by Mr. A. J. Bump, Orosi, Cal., was made in a ten year old vineyard of Muscat Grapes.

Owing to depletion of soil fertility the yields were not very satisfactory, but through the use of fertilizers containing potash a marked increase has been obtained as shown by the following results:

\begin{tabular}{|c|c|c|c|c|c|}
\hline \multirow{3}{*}{$\begin{array}{c}\text { Plot } \\
1\end{array}$} & \multirow{3}{*}{$\begin{array}{l}\begin{array}{c}\text { Amount of fertilizer material } \\
\text { applied per acre in pounds }\end{array} \\
\text { No Fertilizer }\end{array}$} & \multicolumn{2}{|c|}{$\begin{array}{l}\text { Yield per acre } \\
\text { in pounds }\end{array}$} & \multicolumn{2}{|c|}{$\begin{array}{l}\text { Increase over } \\
\text { unfertilized plot } \\
\text { in pounds }\end{array}$} \\
\hline & & 1908 & 1909 & 1908 & 1909 \\
\hline & & 1854 & 2028 & - & - \\
\hline 2 & $\begin{array}{l}120 \text { Sulfate of Potash } \\
600 \text { Superphosphate } \\
180 \text { Nitrate Soda }\end{array}$ & 2624 & 2522 & 770 & 494 \\
\hline 3 & $\begin{array}{l}600 \text { Superphosphate } \\
180 \text { Nitrate Soda }\end{array}$ & 2088 & 2132 & 234 & 104 \\
\hline
\end{tabular}

The test on grapes described on the following page was made in the vineyard of F. C. Lewis, Fowler, Cal. "Thompson's Seedless" was selected for this experiment, and the results, reported for two years show that potash was essential to the largest yields, a good profit being obtained from its use.

\begin{tabular}{|c|c|c|c|c|c|}
\hline \multirow{3}{*}{$\begin{array}{c}\text { Plot } \\
1 \\
1\end{array}$} & \multirow{3}{*}{$\begin{array}{l}\begin{array}{c}\text { Amount of fertilizer material } \\
\text { applied per acre in pounds }\end{array} \\
\text { No fertilizer }\end{array}$} & \multicolumn{2}{|c|}{$\begin{array}{l}\text { Yield per acre } \\
\text { in pounds }\end{array}$} & \multicolumn{2}{|c|}{$\begin{array}{l}\text { Increase over } \\
\text { unfertilized plot } \\
\text { in pounds }\end{array}$} \\
\hline & & 1908 & 1909 & 1908 & 1909 \\
\hline & & 2391 & 3746 & - & - \\
\hline 2 & $\begin{array}{l}120 \text { Muriate Potash } \\
600 \text { Superphosphate } \\
180 \text { Nitrate Soda }\end{array}$ & 5211 & 4950 & 2820 & 1204 \\
\hline 3 & $\begin{array}{l}600 \text { Superphosphate } \\
180 \text { Nitrate Soda }\end{array}$ & 4640 & 4550 & 2249 & 804 \\
\hline
\end{tabular}


Experiment on Seedless Raisin Grapes, by F. C. Lewis, Fowler, Cal.

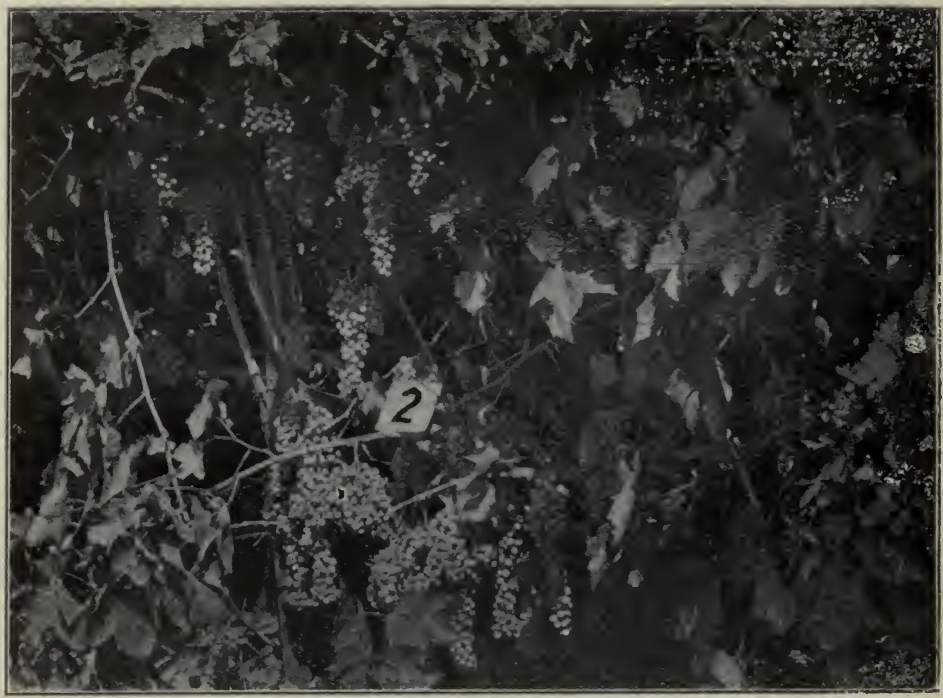

Plot No. 2 Fertilized with High Grade POTASH Fertilizer

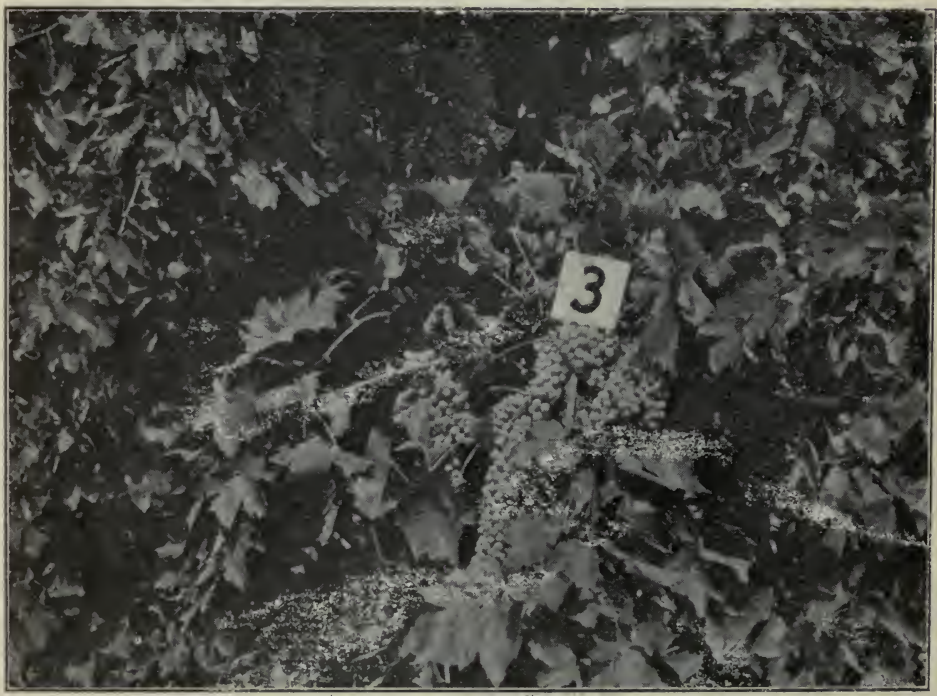




\section{EXPERIMENT ON ORANGLS}

The results of the following experiments made at four different farms, near Porterville and Riverside, should be carefully studied by the practical grower. These trials show large increases produced by using potash fertilizers in conjunction with nitrogen and phosphoric acid.

Experiment by W. H. Grant, Porterville, Cal., Oranges on black adobe over clay subsoil.

\begin{tabular}{|c|c|c|c|c|c|}
\hline \multirow[t]{2}{*}{ Plot } & \multirow[t]{2}{*}{$\begin{array}{l}\text { Fertilizer applied per acre } \\
\text { in pounds }\end{array}$} & \multicolumn{2}{|c|}{$\begin{array}{l}\text { Yield per acre } \\
\text { in pounds }\end{array}$} & \multicolumn{2}{|c|}{$\begin{array}{l}\text { Increase over } \\
\text { unfertilized plot } \\
\text { in pounds }\end{array}$} \\
\hline & & 1908 & 1909 & 1908 & 1909 \\
\hline 1 & No fertilizer & 12285 & 11660 & - & $\longrightarrow$ \\
\hline 2 & $\begin{array}{l}120 \text { Sulfate Potash } \\
600 \text { Superphosphate } \\
180 \text { Nitrate Soda }\end{array}$ & 17940 & 23328 & 5655 & 11668 \\
\hline 3 & $\begin{array}{l}600 \text { Superphosphate } \\
180 \text { Nitrate Soda }\end{array}$ & 15765 & 17280 & 3480 & 5620 \\
\hline
\end{tabular}

Average increase from about $\$ 3.50$ spent for Potash 4,112 pounds Oranges. See photo page 17 .

Experiment by H. C. Carr, Porterville, Cal., Navel Oranges, on deep loam soil (clay subsoil).

\begin{tabular}{|c|c|c|c|}
\hline Plot & $\begin{array}{c}\text { Fertilizer applied per acre } \\
\text { in pounds }\end{array}$ & $\begin{array}{l}\text { Yield pe: acre } \\
\text { Picking boxes }\end{array}$ & $\begin{array}{c}\text { Increase per acre } \\
\text { over } \\
\text { unfertilized plot }\end{array}$ \\
\hline 1 & No fertilizer & 648 & - \\
\hline 2 & $\begin{array}{l}600 \text { Superphosphate } \\
180 \text { Sulfate Potash } \\
150 \text { Dried Blood. }\end{array}$ & 864 & 216 \\
\hline 3 & $\begin{array}{l}600 \text { Superphosphate } \\
150 \text { Dried Blood }\end{array}$ & 756 & 108 \\
\hline
\end{tabular}

The increase from about $\$ 5.00$ worth of Potash, was 108 boxes. See photo page 18. 
Experiment by O. K. Kelsey. Riverside, Cal., on sandy loam soil.

\begin{tabular}{c|c|c|c}
\hline Plot & $\begin{array}{c}\text { Fertilizer applied per acre } \\
\text { in pounds }\end{array}$ & $\begin{array}{c}\text { Yield pe- acre } \\
\text { in packed boxes }\end{array}$ & $\begin{array}{c}\text { increase per acre due } \\
\text { to potash }\end{array}$ \\
\cline { 2 - 3 } 2 & $\begin{array}{c}320 \text { Sulfate Potash } \\
\text { 1440 Superphosphate } \\
640 \text { Nitrate Soda }\end{array}$ & 391 & 61 \\
3 & $\begin{array}{c}1440 \text { Superphosphate } \\
640 \text { Nitrate Soda }\end{array}$ & 330 & \\
\hline
\end{tabular}

Notwithstanding the heavy application, Potash gave a good profit, 61 boxes of Oranges from about $\$ 9.00$ worth of Potash. See photo page 19.

Experiment by W. E. Sprott, Porterville, Cal., Navel Oranges, sandy loam soil.

\begin{tabular}{|c|c|c|c|}
\hline Plot & $\begin{array}{l}\text { Fertilizer applied per acre } \\
\text { in pounds }\end{array}$ & $\begin{array}{l}\text { Yield per acre } \\
\text { picking boxes }\end{array}$ & $\begin{array}{l}\text { Increase per acre over } \\
\text { unfertilized plot } \\
\text { (picking boxes) }\end{array}$ \\
\hline 1 & No Fertilizer & 335 & \\
\hline 2 & $\begin{array}{l}180 \text { Sulfate of Potash } \\
180 \text { Dried Blood } \\
600 \text { Superphosphate }\end{array}$ & 507 & 172 \\
\hline 3 & $\begin{array}{l}180 \text { Dried Blood } \\
600 \text { Superphosphate }\end{array}$ & 381 & 46 \\
\hline
\end{tabular}

Increase from about $\$ 5.00$ worth of Potash 126 boxes. See photo page 20 . 


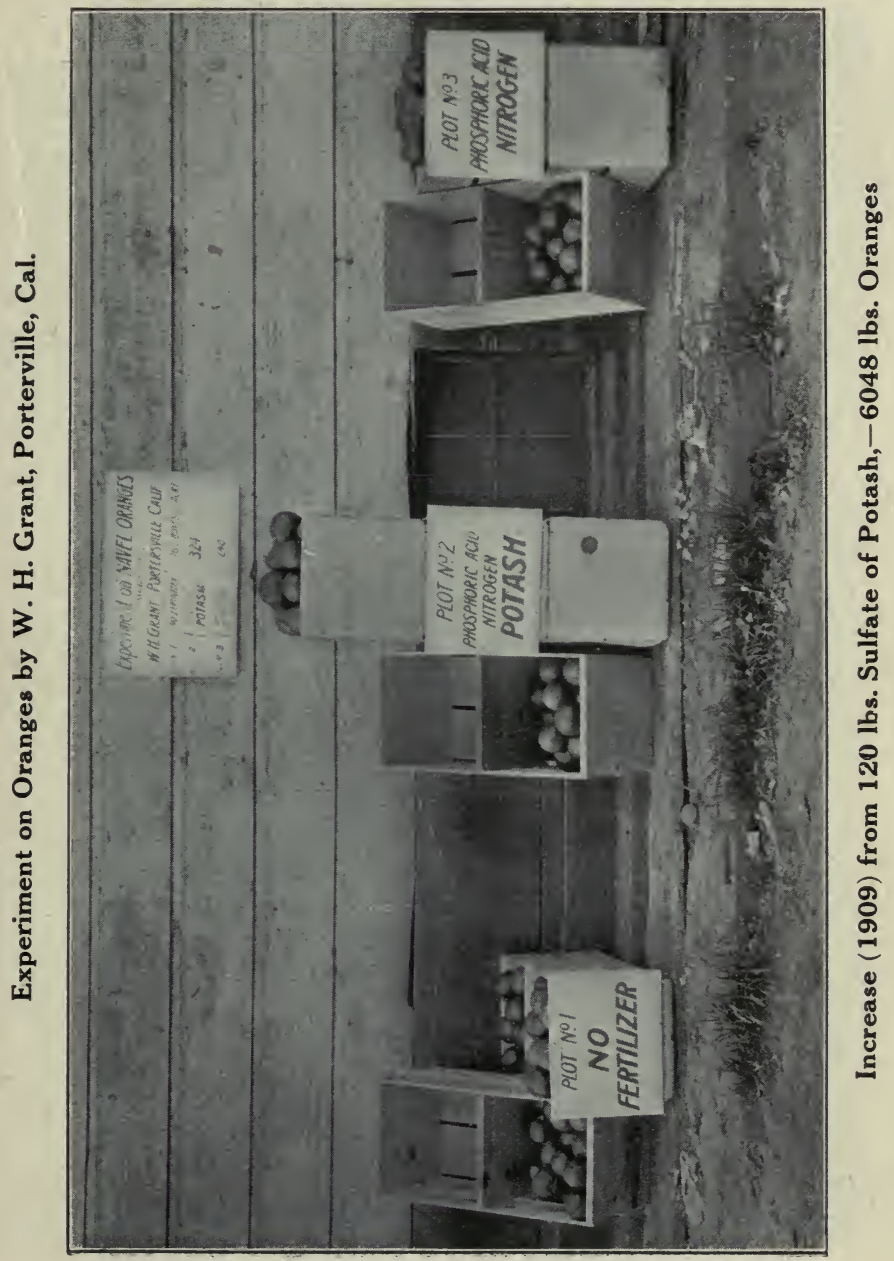




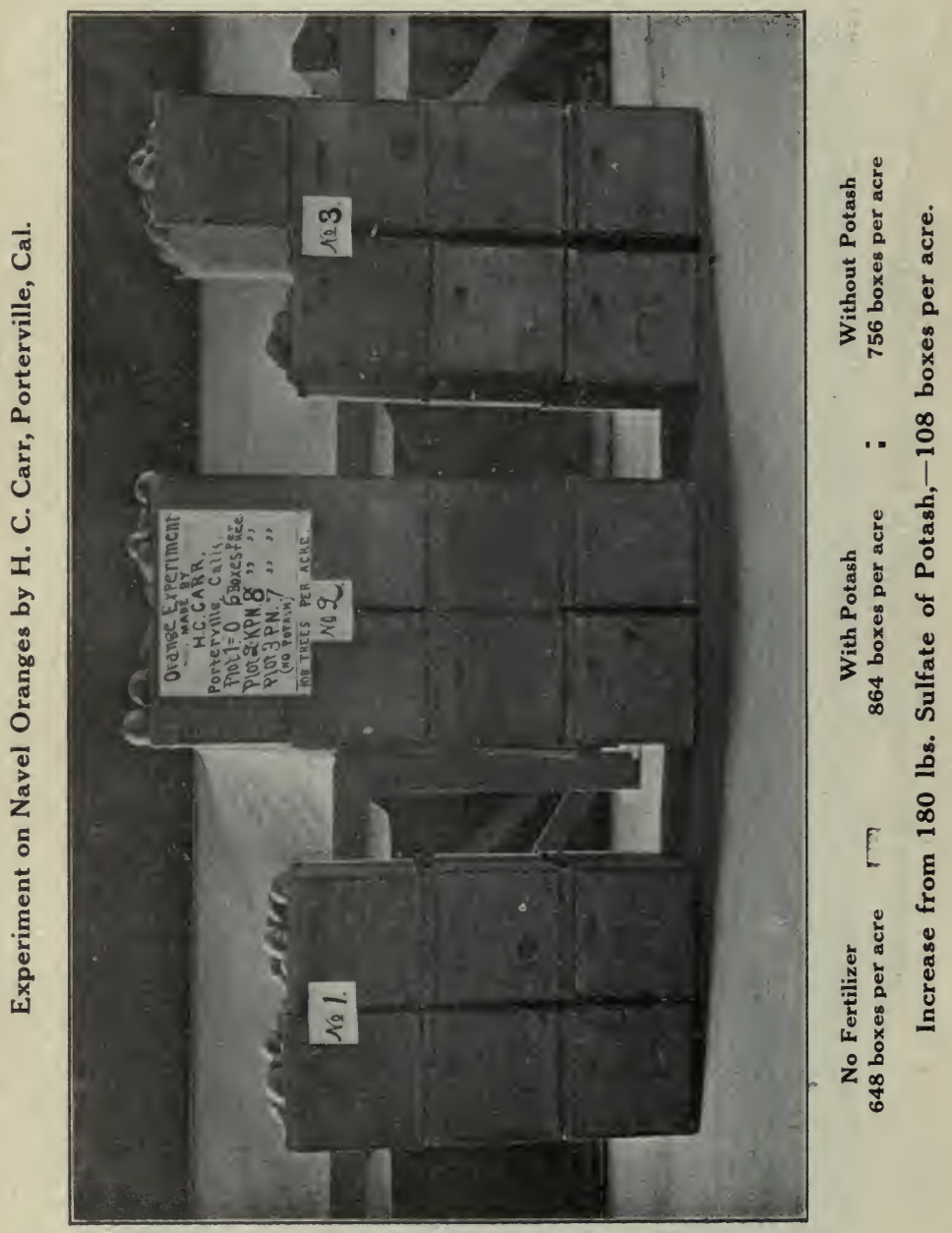


Experiment by Mr. O. K. Kelsey, Riverside, Cal.

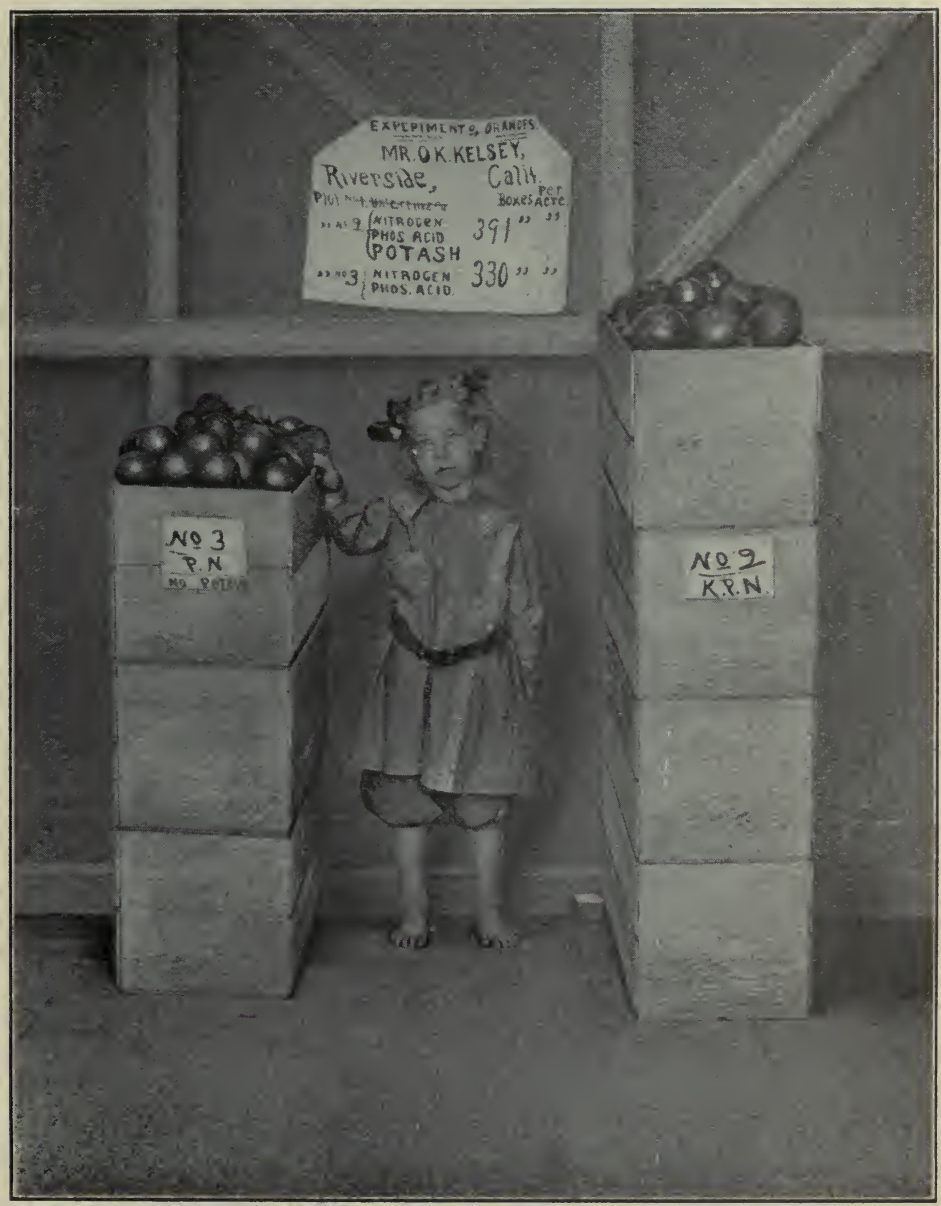

Increase from $320 \mathrm{lbs}$. Sulfate of Potash, -61 boxes. 


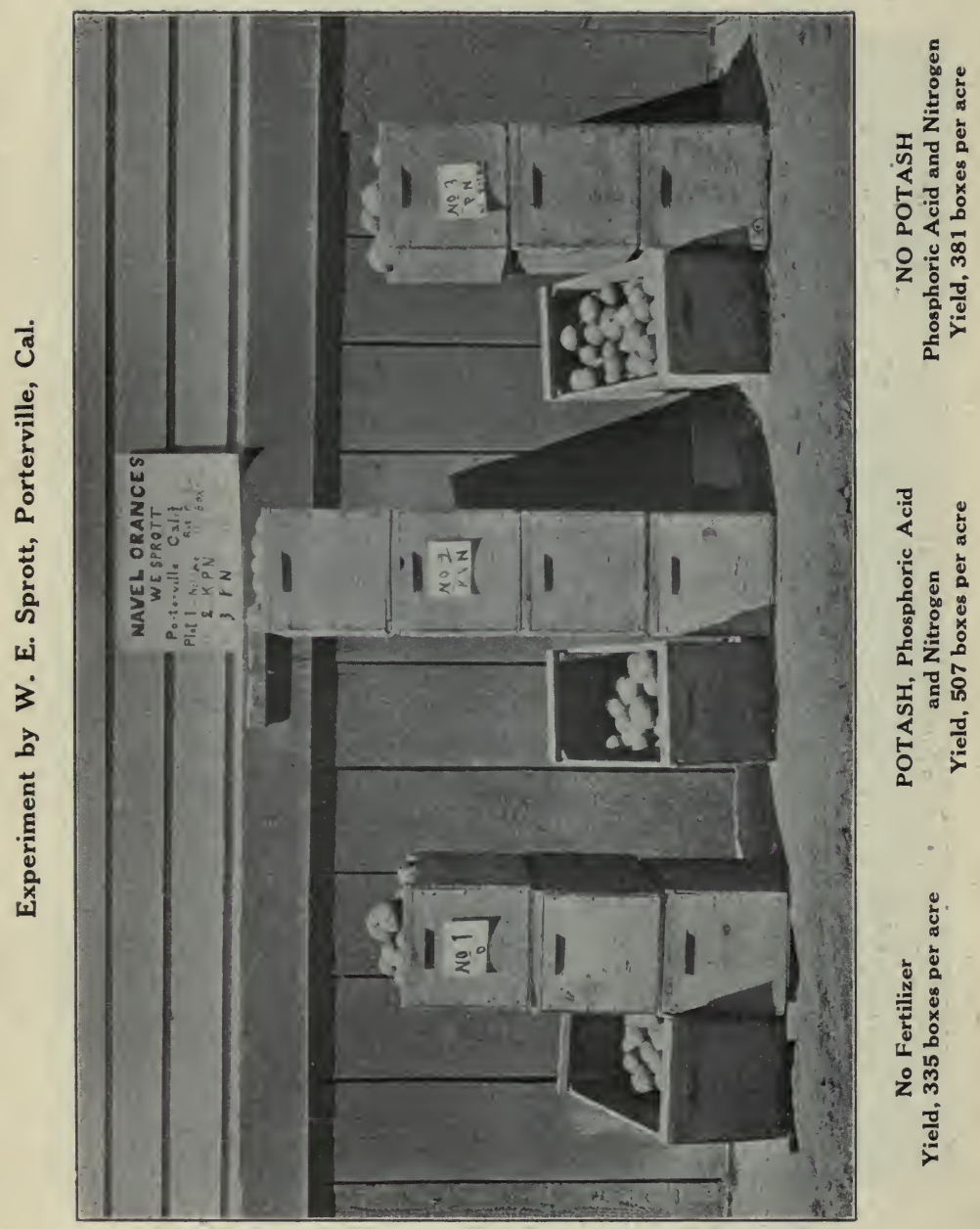




\section{EXPERIMENTS ON LEMONS ON SANDY LOAM SOILS}

Here is a record of two experiments on a more elaborate plan made by Mr. J. C. Davidson, of Chula Vista, Cal., and J. R. Caldwell, of El Cajon, Cal. These tests, like those on oranges, show that citrus fruits in California respond readily to the use of fertilizers and particularly to potash.

\begin{tabular}{|c|c|c|c|c|c|}
\hline \multirow{2}{*}{ Plot } & \multirow{2}{*}{$\begin{array}{l}\text { Fertilizer applied per } \\
\text { acre in pounds }\end{array}$} & \multicolumn{2}{|c|}{ Yield per acre, boxes } & \multicolumn{2}{|c|}{$\begin{array}{l}\text { Increase over } \\
\text { unfertilized plots } \\
\text { per acre }\end{array}$} \\
\hline & & $\begin{array}{l}\text { J. C. Davidson } \\
9 \text { pickings }\end{array}$ & $\begin{array}{l}\text { J.R. Caldwell } \\
4 \text { picking8 }\end{array}$ & Davidson & Caldwell \\
\hline 1 & No fertilizer & 592 & 50 & - & \\
\hline 2 & $\begin{array}{l}240 \text { Sulfate Potash } \\
540 \text { Acid Phosphate }\end{array}$ & Tos & 112 & 116 & 62 \\
\hline 3 & $\begin{array}{l}240 \text { Sulfate Potash } \\
180 \text { Nitrate Soda }\end{array}$ & 675 & 93 & 83 & 43 \\
\hline 4 & $\begin{array}{l}180 \text { Nitrate Soda } \\
540 \text { Acid Phosphate }\end{array}$ & 633 & 104 & 41 & 54 \\
\hline 5 & $\begin{array}{l}240 \text { Sulfate Potarh } \\
540 \text { Acid Phosphate } \\
180 \text { Nitrate Soda }\end{array}$ & 714 & 133 & 122 & 83 \\
\hline 6 & $\begin{array}{l}360 \text { Sulfate Pota.h } \\
270 \text { Nitrate Soda } \\
810 \text { Acid Phosphate }\end{array}$ & 724 & 93 & 132 & 43 \\
\hline
\end{tabular}

The increase from the use of 240 pounds Sulfate of Potash per acre, was 81 boxes in the case of Mr. Davidson's test, and 29 boxes in the test made by Mr. Caldwell. It is well to note that Mr. Caldwell's orchard was only six years old and that only four pickings are reported. 
Experiment by J. C. Davidson, Chula Vista, Cal.

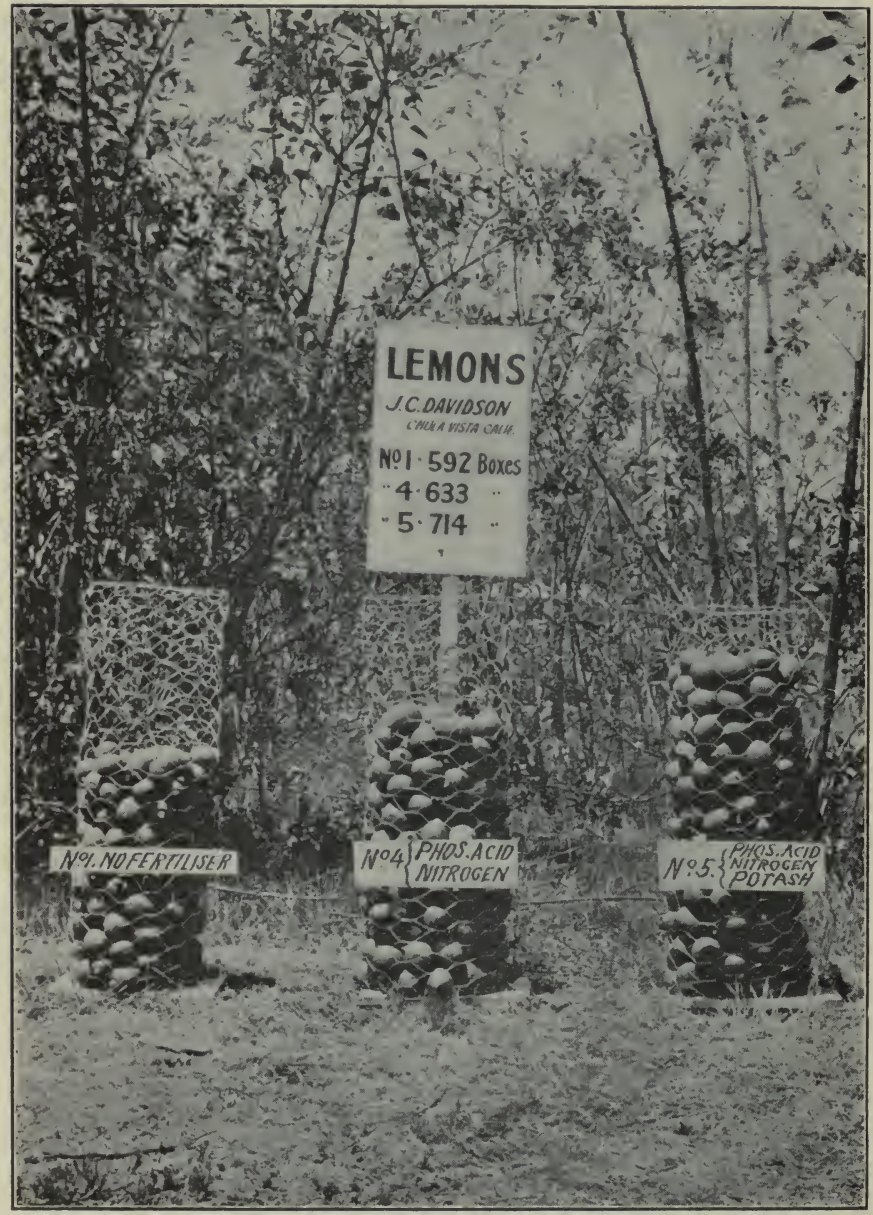

Increase from 240 lbs. per acre, Sulfate of Potash, -81 boxes. 


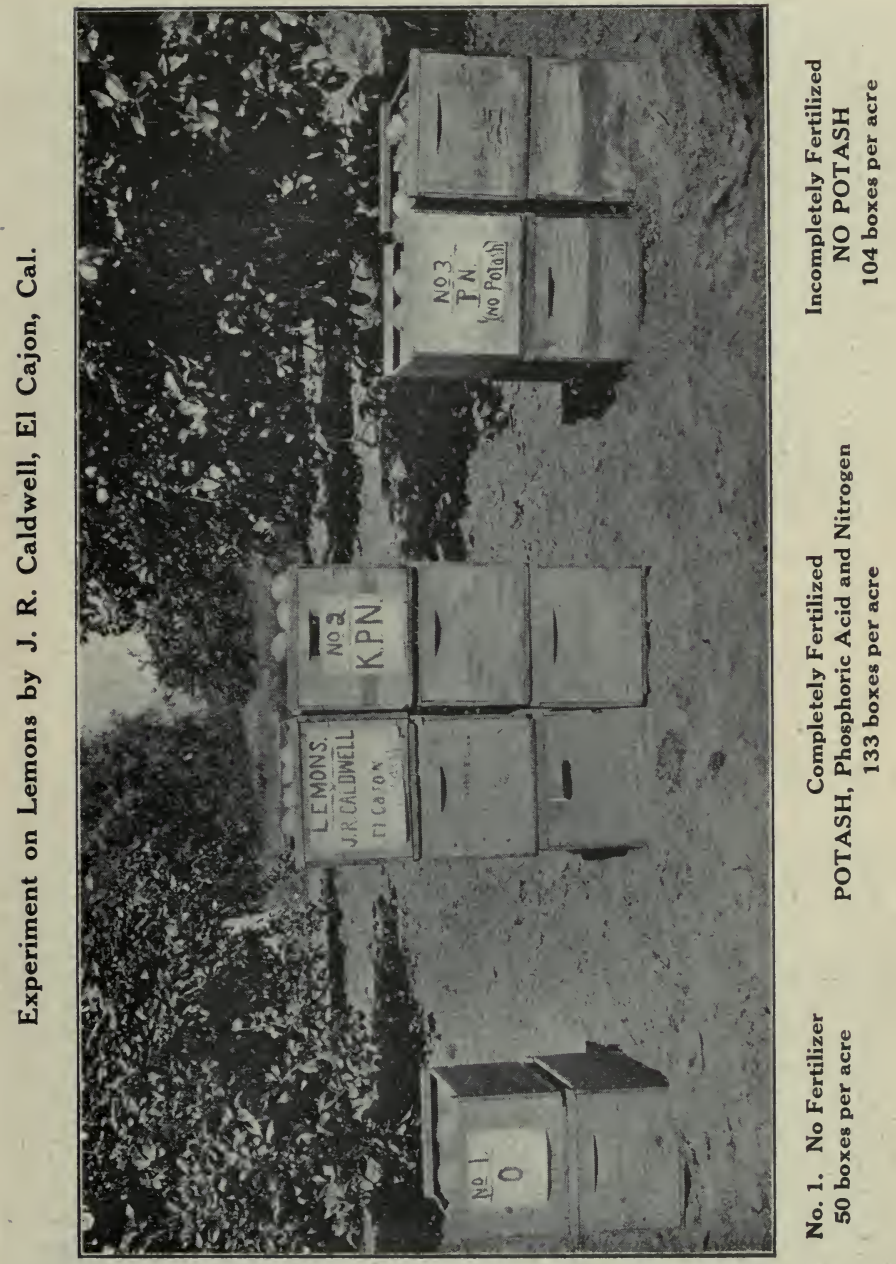




\section{EXPERIMENT ON CELERY}

This experiment was made by W. E. Gerhard, Santa Ana, Cal. It was conducted on loose reclaimed swamp land which had produced a number of crops and was evidently worn out so far as an "available" supply of plant food was concerned. This is shown from the fact that the yield was more than doubled by the fertilizer applications. One third of the 90 crates increase produced from the 1300 pounds of the fertilizer used was due to Potash.

The amount of fertilizer applied to each plot, the yield and the amount of increase are shown in the following table:

\begin{tabular}{c|l|c|c}
\hline Plot & \multicolumn{1}{c|}{$\begin{array}{c}\text { Application per acre } \\
\text { in poun's }\end{array}$} & $\begin{array}{c}\text { Yie!d per acre } \\
\text { in crates }\end{array}$ & $\begin{array}{c}\text { Increase over } \\
\text { unfertilized plot } \\
\text { (in crates' }\end{array}$ \\
\hline 1 & $\begin{array}{l}\text { No fertilizer } \\
750 \text { Acid Phosphate } \\
300 \text { Sulfate Potash } \\
250 \text { Nitrate Soda } \\
750 \text { Acid Phosphate } \\
250 \text { Nitrate Soda }\end{array}$ & 70 & - \\
\hline 3 & 150 & 90 \\
\hline
\end{tabular}

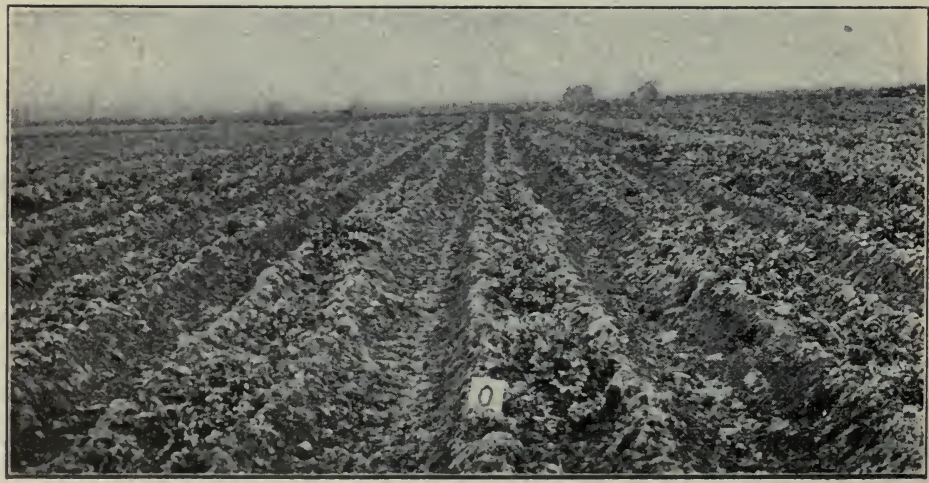

Experiment by W. E. Gerhard, Santa Ana, Cal. No Fertilizer Yield, 70 Crates per acre 
Experiment on Celery by W. E. Gerhard, Santa Ana, Cal.

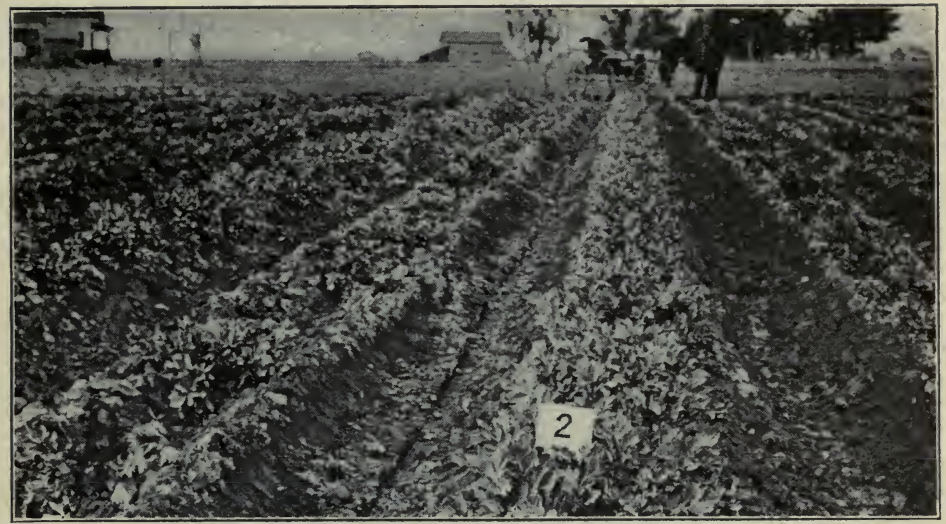

Complete Fertilizer POTASH, Phosphoric Acid and Nitrogen

Yield, 160 Crates per acre

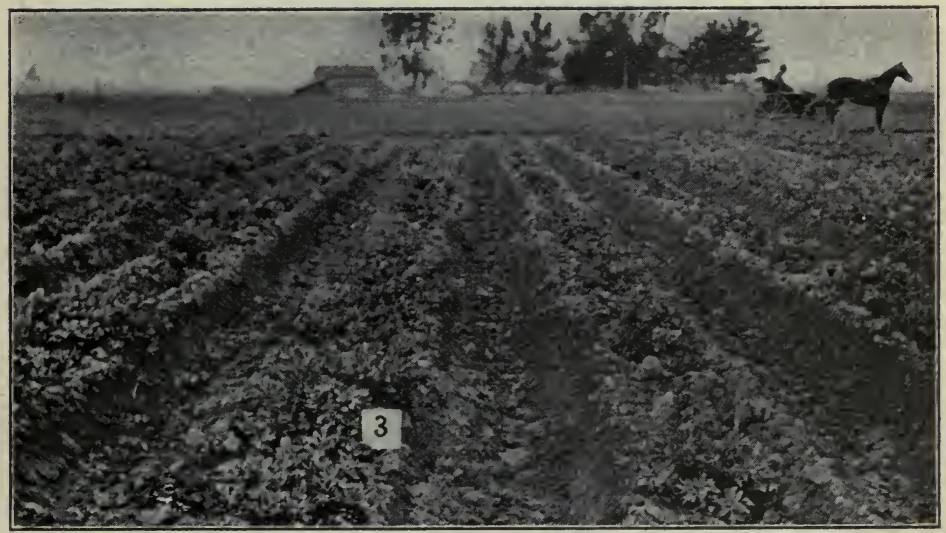

Incomplete Fertilizer NO POTASH (Phosphoric Acid and Nitrogen only) Yield, 130 Crates per acre 
Experiment on Celery by W. E. Gerhard, Santa Ana, Cal.

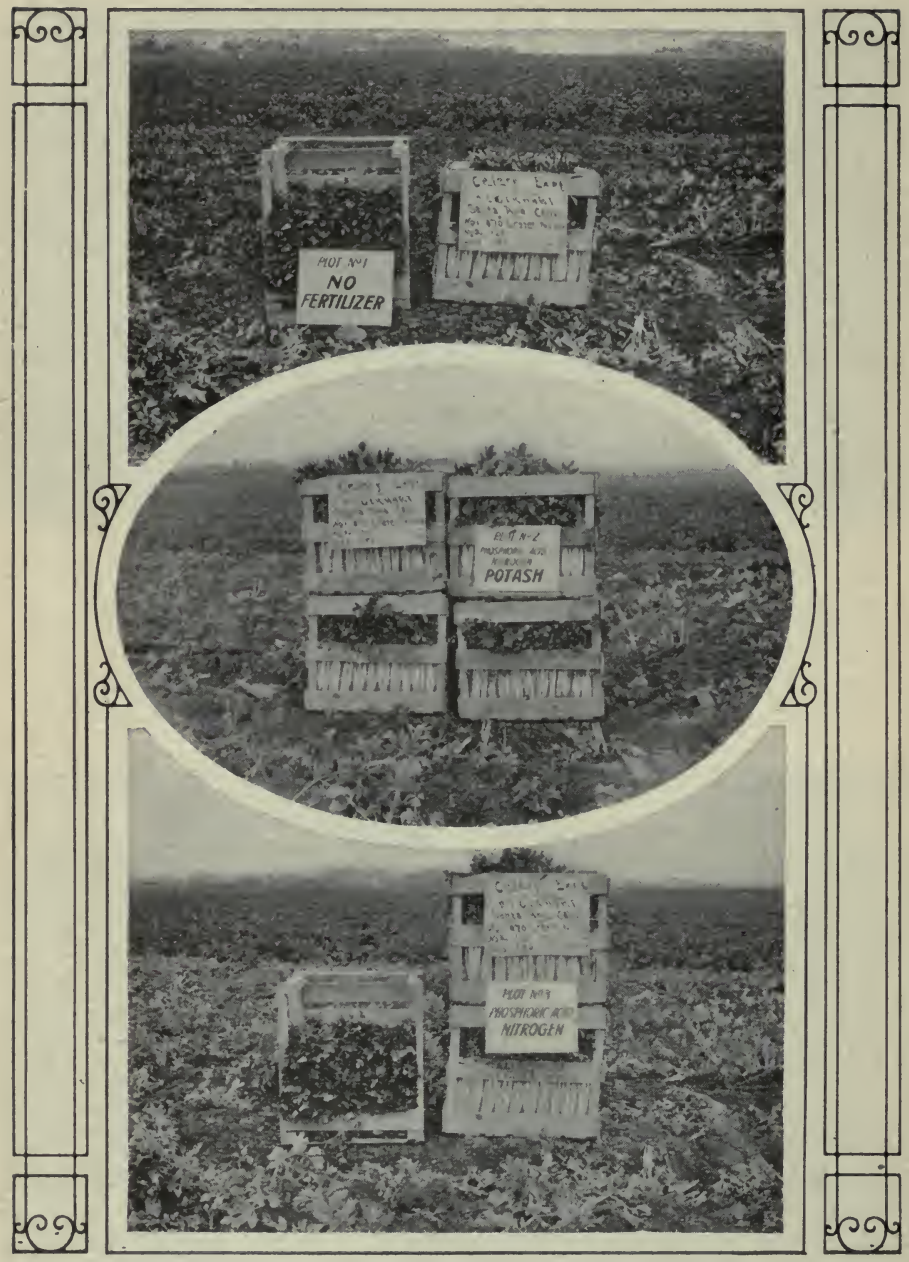

Rolative Yields $\begin{cases}\text { Plot No. } 1 & \text { No Fertilizer (70 crates) } \\ \text { Plot No. } 2 & \text { WITH POTASH (160 crates) } \\ \text { Plot No. } 3 & \text { NO POTASH (130 crates) }\end{cases}$ 


\section{SOME SUGGESTIONS ABOUT USING FERTILIZERS}

In the Introduction to this booklet we mentioned the fact that many farmers and fruit growers often preferred to buy the ingredients, or "simples" as they are called in California, and then make their own mixtures. This is a good way, when the farmer knows how much potash, phosphoric acid, and nitrogen are needed for the soil and the crop to be grown thereon.

Of course, the most expensive of the three essential elements of plant food is the nitrogen, but fortunately Science has come to the aid of the farmer and has shown him how he can obtain a supply of nitrogen at a very moderate cost. In a few words it may be stated that this supply of nitrogen comes from the air, which is used by the bacteria in the soil and by all leguminous crops, of which clover and cowpeas are the most common. Thus, the farmer who wants to get cheap nitrogen, raises a leguminous crop and fertilizes his soil by turning it under. With proper care and study only comparatively small amounts of nitrogen, which is expensive whether in the form of manure or in a commercial fertilizer, need to be bought, and sometimes it may be omitted entirely, especially when leguminous crops are grown in rotation.

It is different with the mineral fertilizers, that is with potash and phosphoric acid. They must be supplied in certain amounts according to the natural fertility of the soil, the requirements of the crop grown, and the system of cropping.

The following suggestions as to the composition of a good àverage fertilizer should prove useful to farmers and fruit growers who wish to make their own mixtures. The 
quantity to be used will run from 250 pounds up to 1,000 and even 2,000 pounds per acre. The largest yields and profits have been obtained by intensive cultivation with corresponding intensive use of fertilizers.

\section{Citrus Fruits} For Growing Trees

Nitrogen $\ldots \ldots \ldots \ldots \ldots .4$ per cent.
Phosphoric Acid....... 8 per cent.
Potash............ 7 per cent.

Sulfate of Potash......... $300 \mathrm{lbs}$.

Nitrate of Soda.......... $500 \mathrm{lbs}$.

Acid Phosphate (16\%)...... $800 \mathrm{lbs}$.

†Bone Meal............. 400 lbs.

$$
2000 \mathrm{lbs} .
$$

From three $1 \mathrm{bs}$. per tree for the first year, to $15 \mathrm{lbs}$. per tree for the sixth year is usually considered a fair application.

$$
\text { For Bearing Trees }
$$

Nitrogen ............ $3 \frac{1}{2}$ per cent.

Phosphoric Acid.... 8 per cent.

Potash............ 12 $1 / 2$ per cent.

Sulfate of Potash ......... $525 \mathrm{lbs}$.

Acid Phosphate (16\%)....... $1000 \mathrm{lbs}$.

Nitrate of Soda..........4 $475 \mathrm{lbs}$

$$
2000 \text { lbs. }
$$

From ten to twenty-five pounds per tree is the usual application.

\section{Deciduous Fruits For Growing Trees}

Nitrogen ........... 3 per cent.

Phosphoric Acid. ..... 9 $1 / 2$ per cent.

Potash............10 per cent.

Nitrate of Soda.......... $400 \mathrm{lbs}$.

Acid Phosphate ( 16 per cent. $\} 1200 \mathrm{lbs}$.

available Phosphoric Acid) $\} 1200 \mathrm{lbs}$

Sulfate of Potash........... $400 \mathrm{lbs}$

†Note-Bone Meal varies in composition. In this formula credit is given for 4 per cent Nitrogen and 8 per cent Phosphoric Acid available during the first year. 


\section{For Bearing Trees \\ Nitrogen............ 2 per cent. \\ Phosphoric Acid...... 9 per cent. \\ Potash.............11 per cent.}

Nitrate of Soda............ 240 lbs. Acid Phosphate (16 per cent.) $\} 8001 \mathrm{bs}$

available Phosphoric Acid. $\} 800 \mathrm{lbs}$. †Steamed Bone Meal......... 520 1bs. Sulfate of Potash........... 440 lbs.

$$
20001 \mathrm{bs} \text {. }
$$

\section{Vegetables, Potatoes, Roots, etc.}

Nitrogen ........... 3 per cent.

Phosphoric Acid.... . . 8 per cent.

Potash ...........11 per cent.

Nitrate of Soda... . . . . . . $400 \mathrm{lbs}$. Acid Phosphate (16\% Avail.) .. 1000 lbs. Sulfate of Potash........... 440 lbs. Filler*................ 160 lbs.

$$
2000 \text { 1bs. }
$$

\section{For Corn, Alfalfa, Clover}

Nitrogen........... 2 per cent.

Phosphoric Acid ... ...8 8 per cent.

Potash.............10 per cent.

Nitrate of Soda............ 120 lbs.

Dried Blood (12\% Nitroge11).... $180 \mathrm{lbs}$. Acid Phosphate (16\% Avail.). 1000 lbs. Muriate of Potash..........4400 lbs. Filler*................. 300 lbs. $20001 \mathrm{bs}$.

This is a good general purpose fertilizer.

*Note-Filler is unnecessary but may be used if it is desired to keep fertilizer in bags after mixing. If omitted, each of the plant food percentages is increased by about eight per cent. It is evident that with $160 \mathrm{lbs}$. of filler to the ton, only 92 per cent as much fertilizer would be required without the filler as with it. With $300 \mathrm{lbs}$. to ton, only $85 \%$ as much.

†Note - Calculated on basis of 1 per cent Nitrogen and 10 per cent. Available Phosphoric Acid. 


\section{For Wheat and Small Grain}

Nitrogen ......... 1 1/2 per cent.

Avail. Phos. Acid.....10 per cent.

Actual Potash......8 8 per cent.

†Bone Meal.............. 780 lbs.

Acid Phosphate (16\% Avail.).. 900 lbs.

Muriate of Potash......... 320 1bs.

2000 lbs.

\section{DESCRIPTION OF FERTILIZER MATERIALS}

\section{Materials for Supplying Potash}

Muriate of Potash contains 50 per cent. of actual potash and is one of the most concentrated of plant food materials. As a rule, a pound of potash costs less in the form of muriate than in any other form of potash and for this reason it is the most popular source of potash in mixed fertilizers or for home mixing. Muriate of potash is not generally used, however, on white potatoes, tobacco or citrus fruits.

Sulfate of Potash is recommended for citrus fruits, white potatoes and tobacco. It may be used upon all crops for which muriate of potash is recommended, and it is sometimes preferred for deciduous as well as citrus fruits. It occurs as a fine dry powder, and is readily adapted for mixing with other fertilizer materials. Sulfate of Potash usually contains 50 per cent. actual potash and is sold under a minimum guarantee of 48 per cent. actual potash.

Kainit is a crude salt; that is, it has not been refined or manufactured other than being ground into a condition ready for application as a fertilizer. It is sold under a

†Note-Bone Meal varies in composition. In this formula credit is given for 4 per cent. Nitrogen and 8 per cent. Phosphoric Acid available during the first year. 
guarantee of 12.4 actual potash and contains potash, both in the forms of sulfate and muriate. It contains salts of magnesia and also common salt. Kainit can be used upon the crops for which muriate of potash is recommended.

\section{Materials Furnishing Phosphoric Acid.}

Materials furnishing phosphoric acid in a highly available form are acid phosphate, dissolved bone and dissolved bone black.

Phosphoric acid in a less readily available form, is to be had in bone meal and Thomas phosphate or basic slag. The amount which is available will depend to a great extent, upon how finely the material is ground.

Ground bone meal contains, as a rule, from 25 to 28 per cent. of total phosphoric acid of which 6 to 8 per cent. may be cons dered available during the first year. It also contains from 1 to 4 per cent. nitrogen. Dissolved bone, acid phosphate and dissolved bone black usually contain from 14 to 17 per cent. available phosphoric acid.

\section{Materials Furnishing Nitrogen}

The principal commercial sources of nitrogen are nitrate of soda, supplying from 15 to 16 per cent of nitrogen: sulfate of ammonia, 19 to 20 per cent. nitrogen, and dried blood from 10 to 14 per cent according to the grade. Tankage, in addition to supplying from 7 to 9 per cent. nitrogen usually contains about an equal amount of phosphoric acid. Of many other sources of nitrogen somewhat less in general use, we will mention dried fish scrap, containing from 7 to 9 per cent. nitrogen and $5 \frac{1}{2}$ to 7 per cent. phosphoric acid, and cotton seed meal, containing $61 / 2$ to 7 per cent. nitrogen and a small amount of phosphoric acid and potash. 
Materials supplying nitrogen should be selected according to their relative availability, so that the plant may have a full supply during the growing season. Nitrate of soda probably furnishes nitrogen in the most available form. Sulfate of ammonia is more slowly available but much more readily ayailable than dried blood, tankage or biproducts of the slaughter house.

The interests of the farmer are best conserved by an intelligent interest on his part, in the composition of the fertilizers which he uses. Valuable suggestions have been given about good general purpose formulas and how to make them. It is possible however, with a better knowledge of the composition of the materials furnishing the elements, nitrogen phosphoric acid and potash, tu compound fertilizers according to any desired formula. Since "experience is the best teacher," the farmer who will follow our suggestions pertaining to plot experiments will have an advantage over his neighbor who has not made practical tests with the plant food elements.

As a result of our own experience we are confident that if these experiments are carefully conducted, even though it may be shown that on some soils and for some crops one element may be more important than another, the need of an available supply of potash will be demonstrated, and when put to the test of profit in dollars and cents, the conclusion will be that "Potash Pays." 



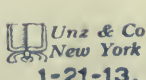




\section{UNIVERSITY OF CALIFORNIA LIBRARY \\ BERKELEY}

Return to desk from which borrowed.

This book is DUE on the last date stamped below.

14Jun'50J 6 


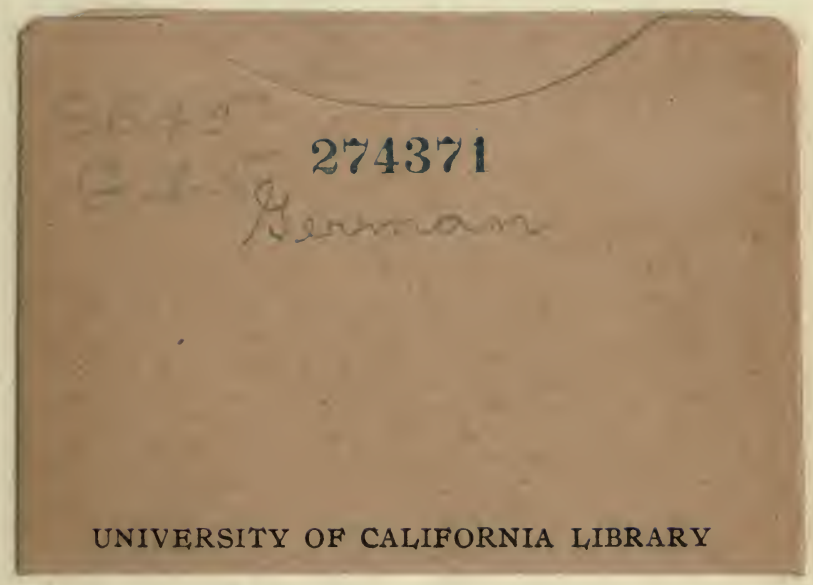


